\title{
Development of Mn-type Lithium-Ion Batteries and Study for a Pure Electric Buses Applications
}

\author{
Shigeru Motohira, a,d,* Hiroki Morino, ${ }^{a}$ Yasuhiro Matsumoto, ${ }^{a}$ \\ Kenichi Tomozawa, ${ }^{\mathrm{b}}$ Masao Uede, ${ }^{\mathrm{b}}$ Hironori Ozawa, ${ }^{\mathrm{c}}$ and Takashi OGIHara ${ }^{\mathrm{d}}$
}

\author{
${ }^{a}$ Hokuriku Electric Power Company (2-54 Hisakata, Toyama-shi, Toyama 930-0848, Japan) \\ ${ }^{b}$ Chugai Ro Co., Ltd. (2-4 Chikko-Shinmachi, Nishi-ku, Sakai 592-8331, Japan) \\ 'Enax. Co., Ltd. (11-19 Otowa 2, Bunkyo-ku, Tokyo 112-0013, Japan) \\ ${ }^{d}$ University of Fukui (9-1 Bunkyo 3, Fukui-shi, Fukui 910-8507, Japan)
}

Received January 28, 2009 ; Accepted November 15, 2009

\begin{abstract}
From the viewpoint of reducing carbon dioxide emissions, the practical use of electric buses has been expected to be one of the effective solutions to global warming. Even though lithium-ion batteries using lithium manganese oxide have been studied for use in electric vehicles, it is still necessary to improve their characteristics such as energy density, maximum operating temperature and cycle performance. Manganese oxide lithium-ion batteries for an electric bus developed by internal-combustion spray pyrolysis methods and its performance in an actual road test have been studied. The performance of the electric bus was satisfactory; the bus could run for $74 \mathrm{~km}$ on a full charge.
\end{abstract}

Key Words : Lithium-Ion Batteries, Electric Bus, Spinel Type, Spray Pyrolysis, Energy Saving

\section{Introduction}

As a measure against global warming, the reduction in carbon dioxide emissions is required. Electric vehicles (EVs) are effective for achieving this aim. Electric buses are effective for reducing carbon dioxide emissions because public transport vehicles are used for mass transport. Therefore, a further reduction of carbon dioxide emissions is possible if diesel-engine buses are replaced with electric buses.

Conventionally, the power sources of electric buses have been lead-acid batteries. ${ }^{1)}$ However, many batteries must be mounted because their energy density and power density are small. As a result, the vehicle body becomes heavy and riding capacity is reduced.

Spinel-type lithium manganese oxide batteries have been proposed owing to their lower cost, greater safety and greater quantity of natural resources than lithium cobalt oxide lithium batteries. Therefore, their applications in EVs, railcars ${ }^{2)}$ and electric energy storage devices have been encouraged. However, lithium manganese oxide batteries exhibit a marked deterioration in their cycle performance and maximum operating temperatures at high temperatures. ${ }^{3,4)}$ Therefore, their improvement is an issue that must resolved in order to apply them as a power supply of electric buses.

As a method of improving the properties of spinel-type lithium manganese oxide batteries, doping with different types of metals has been reported to be effective., 6) $\mathrm{On}$ the other hand, at University of Fukui, internal-combustion spray pyrolysis, which enables the production of cathode materials with doped aluminum for lithium-ion batteries, has been developed. ${ }^{7.8)}$ When this technique is used, cathode materials can be produced in large quanti- ties at a low cost. Furthermore, the particles produced are small, leading to the improvement in the performance of lithium-ion batteries.

In this study, to improve battery cycle performance and maximum operating temperature, the cathode materials of lithium-ion batteries were produced by internalcombustion spray pyrolysis with doped aluminum and the electrochemical characteristics of the batteries were examined. Furthermore, the cathode materials produced by this method were used for the lithium-ion batteries. These batteries were mounted on the electric bus developed by the authors ${ }^{9}{ }^{10)}$ and the battery characteristics were examined in running tests.

\section{Requirements for Batteries}

The target specifications required for the practical use of electric buses and the battery performance required to achieve these targets were found by a numerical formulas.

\section{1 Demand specifications of electric bus}

The following specifications are required for the electric bus.

(a) Distance covered km: More than $50 \mathrm{~km}$

Because $65.1 \%$ of community buses follow a course less than $20 \mathrm{~km}$ in length, the target distance covered $\mathrm{km}$ of the electric bus was more than $50 \mathrm{~km}$.

\section{(b) Battery life: More than three years}

It is assumed that the battery price will in the future become one-twentieth of the current price; for the cost of an electric bus battery to become equal to that of a battery for a diesel bus, the battery life should be more than three years.

(c) Maximum power: $120 \mathrm{~kW}$ 
The maximum power of a motor installed in an electric bus $120 \mathrm{~kW}$.

(d) Possible use under summer temperature conditions

Lithium-ion batteries have maximum operating temperature problems.

\section{2 Required specifications of lithium-ion batteries}

Author calculates demand specifications of the battery for the electric bus as follow; it gives a detailed description.

2. 2. 1 Required specifications of the cathode of the cells To remodel a diesel-engine bus into an electric bus, the weight of the batteries to be mounted was investigated. The engine, transmission and fuel tank were removed from the diesel-engine bus. Their gross weight was about $700 \mathrm{~kg}$. The total weight of the motor and inverter installed in the electric bus was about 200 $\mathrm{kg}$. Therefore, the weight of the batteries must be less than $500 \mathrm{~kg}$.

The energy consumption rate $\left(\mathrm{E}_{\mathrm{c}}\right)$ of the electric bus was assumed to be $2 \mathrm{~km} / \mathrm{kWh}$, as predicted from a simulation result. When the capacity deterioration $\left(\eta_{1}\right)$ due to aging was estimated to be $30 \%$, and the available capacity rate $\left(\eta_{2}\right)$ of the batteries was assumed to be $90 \%$, the required battery energy $\left(C_{b}\right)$ for the electric bus to run $50 \mathrm{~km}(\mathrm{D})$ was calculated as follows.

$$
C_{b}=D \cdot\left(1-\eta_{1}\right) \cdot \eta_{2} / E_{c}
$$

Substituting into $D=50 \mathrm{~km}, \mathrm{E}_{\mathrm{c}}=2 \mathrm{~km} / \mathrm{kWh}, \eta_{1}=0.3$ and $\eta_{2}=0.9 \mathrm{Eq}$. (1), the required battery energy $\left(\mathrm{C}_{\mathrm{b}}\right)$ was $40 \mathrm{kWh}$.

The weight of the cells was $80 \%$ of the weight $\left(\mathrm{W}_{\mathrm{b} 1}\right)$ of the battery modules. The target gross weight $\left(\mathrm{W}_{\mathrm{b} 2}\right)$ of the cells and their target energy density (E) were calculated as follows.

$$
\begin{gathered}
\mathrm{W}_{\mathrm{b} 2}=\mathrm{W}_{\mathrm{b} 1} \cdot 0.8 \\
\mathrm{E}=\mathrm{C}_{\mathrm{b}} / \mathrm{W}_{\mathrm{b} 2}
\end{gathered}
$$

Substituting $\mathrm{W}_{\mathrm{b} 1}=500 \mathrm{~kg}$ into Eq. (2), the gross weight $\left(\mathrm{W}_{\mathrm{b} 2}\right)$ of the cells was $400 \mathrm{~kg}$.

Substituting $\mathrm{C}_{\mathrm{b}}=40 \mathrm{kWh}$ and $\mathrm{W}_{\mathrm{b} 2}=400 \mathrm{~kg}$ into Eq. (3), the energy density (E) of the cells was $100 \mathrm{Wh} / \mathrm{kg}$.

The average weight of the cathode materials to be used in the cells was $30 \%$ of the whole cell weight. Therefore, the target capacity $\left(\mathrm{P}_{\mathrm{ah}}\right)$ of the cathode materials was calculated as below. In the calculation, the average voltage $\left(\mathrm{V}_{\mathrm{c}}\right)$ of the cells was assumed to be $3.8 \mathrm{~V}$.

$$
\mathrm{P}_{\mathrm{ah}}=\mathrm{E} /\left(\mathrm{V}_{\mathrm{c}} \cdot 0.3\right)
$$

Substituting $\mathrm{E}=100 \mathrm{Wh} / \mathrm{kg}$ and $\mathrm{V}_{\mathrm{c}}=3.8 \mathrm{~V}$ into Eq. (4), the discharge capacity $\left(\mathrm{P}_{\text {ah }}\right)$ was $90 \mathrm{mAh} \cdot \mathrm{g}^{-1}$.

\subsubsection{Required specifications of the cells}

The structure of each cell was of the laminated layered type, which has better safety and heat radiation characteristics than the cylindrical type.

Because the gross weight $\left(\mathrm{W}_{\mathrm{b} 2}\right)$ of each cells was 400 $\mathrm{kg}$ and the weight $\left(\mathrm{w}_{\mathrm{c}}\right)$ of each cell was almost $250 \mathrm{~g}$, the total number $(\mathrm{N})$ of cells was calculated as follows.

$$
\mathrm{N}=\mathrm{W}_{\mathrm{b} 2} / \mathrm{W}_{\mathrm{c}}
$$

Substituting $\mathrm{W}_{\mathrm{b} 2}=400 \mathrm{~kg}$ and $\mathrm{w}_{\mathrm{c}}=250 \mathrm{~g}$ into Eq. (5), the total number $(\mathrm{N})$ of cells was 1,600 .

The voltage range of the inverter for the main motor is $250 \mathrm{~V}-425 \mathrm{~V}$. On the other hand, the voltage range of the cell is $3.0 \mathrm{~V}-4.2 \mathrm{~V}$. Therefore, the battery modules consisted of 90 cells connected in series, and the voltage range of the battery modules was assumed to be 270 $\mathrm{V}-378 \mathrm{~V}$. Considering convenience in practical use, 15 series $(45 \mathrm{~V}-63 \mathrm{~V})$ were chosen for one module. Therefore, the required specifications of the cell were calculated as follows.

\section{(a) Energy density}

The target energy density of the cells was $100 \mathrm{Wh} /$ $\mathrm{kg}$, as determined using Eq. (3).

(b) Number of cells connected in parallel $\left(P_{n}\right)$

$$
\mathrm{P}_{\mathrm{n}}=\mathrm{W}_{\mathrm{b} 2} /\left(\mathrm{S} \cdot \mathrm{W}_{\mathrm{c}}\right)
$$

Substituting $\mathrm{W}_{\mathrm{b} 2}=400 \mathrm{~kg}, \mathrm{~S}=90$ series and $\mathrm{w}_{\mathrm{c}}=250 \mathrm{~g}$ into Eq. (6), the number of cells connected in parallel $\left(\mathrm{P}_{\mathrm{n}}\right)$ was 18 .

(c) Number of cycles

The target life is three years. Because a bus is used 300 days in a year, and then the battery cycle life is expected more than 1,000 cycles as a target.

\section{(d) Power density}

Because the maximum power $\left(\mathrm{P}_{\mathrm{B}}\right)$ of the electric bus is $120 \mathrm{~kW}$, the total number $(\mathrm{N})$ of the cells is 1,620 and the weight of each cell is $250 \mathrm{~g}\left(\mathrm{w}_{\mathrm{c}}\right)$, the output density of the cells required $\left(\mathrm{P}_{\mathrm{c}}\right)$ is calculated as follows.

$$
\mathrm{P}_{\mathrm{c}}=\mathrm{P}_{\mathrm{B}} /\left(\mathrm{N} \cdot \mathrm{w}_{\mathrm{c}}\right)
$$

Substituting the above values into Eq. (7), the output density required $\left(\mathrm{P}_{\mathrm{c}}\right)$ was $300 \mathrm{~W} / \mathrm{kg}$.

\section{(e) Maximum operating temperature}

With an outside temperature of $36^{\circ} \mathrm{C}$, the temperature inside the vehicle was $38^{\circ} \mathrm{C}$ without an air conditioner. With an outside temperature of $40{ }^{\circ} \mathrm{C}$, the temperature inside the vehicle was assumed to be $42^{\circ} \mathrm{C}$. To install the battery in the inside of the bus, the target maximum operating temperature of the cell was set to be $45^{\circ} \mathrm{C}$. The above-mentioned results are summarized in Table 1.

Table 1 Target characteristics.

\begin{tabular}{l|c}
\hline Cathode & Target \\
\hline Discharge capacity $(\mathrm{mAh} / \mathrm{g})$ & 90 \\
\hline \multicolumn{2}{|c}{} \\
\hline Cell & Target \\
\hline Energy density $(\mathrm{Wh} / \mathrm{kg})$ & 100 \\
\hline Number of cycles $(\mathrm{times})$ & 1,000 \\
\hline Power density $(\mathrm{W} / \mathrm{kg})$ & 300 \\
\hline Maximum operating temperature $\left({ }^{\circ} \mathrm{C}\right)$ & 45 \\
\hline
\end{tabular}




\section{Experimental}

\section{1 Preparation of lithium-ion batteries mounted on} electric bus

3. 1. 1 Preparation of cathode materials and test cells

$\mathrm{LiNO}_{3}, \mathrm{Mn}\left(\mathrm{NO}_{3}\right)_{2} \cdot 6 \mathrm{H}_{2} \mathrm{O}$ and $\mathrm{Al}\left(\mathrm{NO}_{3}\right)_{3} \cdot 9 \mathrm{H}_{2} \mathrm{O}$ were used as starting materials. $\mathrm{LiNO}_{3}$ and $\mathrm{Mn}\left(\mathrm{NO}_{3}\right)_{2} \cdot 6 \mathrm{H}_{2} \mathrm{O}$ were prepared so that the molar ratio of $\mathrm{Li}$ to $\mathrm{Mn}$ was $1: 2$. The mixture was dissolved in distilled water to prepare a $1.0 \mathrm{~mol} \cdot \mathrm{dm}^{-3}$ starting aqueous solution. The concentration of $\mathrm{Al}\left(\mathrm{NO}_{3}\right)_{3} \cdot 9 \mathrm{H}_{2} \mathrm{O}$ ranged from 5 to $10 \mathrm{~mol} \%$ for $\mathrm{Mn}\left(\mathrm{NO}_{3}\right)_{2} \cdot 6 \mathrm{H}_{2} \mathrm{O}$. These were composed by internal-combustion spray pyrolysis and used as the cathode materials.

The $\mathrm{LiAl}_{0.05} \mathrm{Mn}_{1.95} \mathrm{O}_{4}$ electrode of the test cells consisted of $80 \mathrm{wt} \% \mathrm{LiAl}_{0.05} \mathrm{Mn}_{1.95} \mathrm{O}_{4}, 10 \mathrm{wt} \%$ acetylene black and $10 \mathrm{wt} \%$ polyvinylidene fluoride as a binder. $N$-Methy $1-2-$ pyrrolidinone (NMP) was added to the bindes in the form of a slurry, which was coated on an aluminum sheet using a doctor blade. The sheet was dried in an oven at $120{ }^{\circ} \mathrm{C}$ for $24 \mathrm{~h}$ under vacuum. ${ }^{7)}$

Lithium metal (Honjo Chemical Co., Ltd) was used as the anode of the test cells. A porous polypropylene sheet (Heist Japan, Co., Ltd) was used as a separator. The electrolyte was $1 \mathrm{M} \mathrm{LiPF}_{6}$ dissolved in an ethylene carbonate (EC)/diethyl carbonate (DEC) (1/1 by volume) solution. The concentration of $\mathrm{LiPF}_{6}$ was adjusted to $1 \mathrm{~mol} \cdot \mathrm{dm}^{-3}$ The test cells were assembled in a glove box filled with argon gas.

\section{1. 2 Preparation of cells We used} $\mathrm{LiAl}_{0.05} \mathrm{Mn}_{1.95} \mathrm{O}_{4}$ for the laminated layered type cells in the battery modules of the electric bus. The anode of the cells was made of graphite and hard carbon (Osaka Gas Co., Ltd). The average particle diameter was $10 \mu \mathrm{m}$. The cells had a layered laminated sheet structure $(170 \mathrm{~mm} \times$ $160 \mathrm{~mm} \times 5.3 \mathrm{~mm}$ ). The average weight of the cells was $233 \mathrm{~g}$.

\section{1. 3 Structure of the battery modules}

batteries used in the electric bus consisted of 1,620 lithium ion cells. Six modules were connected in series; in each module, 15 units, each consisting of 18 cells connected in parallel, were arranged in series. Battery management systems (BMS) were installed in each series of cells. They consist of a 4-ohm bypass resistor with a switch, voltage sensors and a thermal sensing device.

When the voltage of the parallel cells reaches $4.2 \mathrm{~V}$ during charging, an electric current passes through the 4-ohm resistor when the switch is closed, and the voltage of the cells is lowered. In addition, when the voltage of the parallel cells reaches $4.3 \mathrm{~V}$, an overcharging signal is transmitted to the battery charger.

On the other hand, when the voltage of the parallel cells decreased to $3.0 \mathrm{~V}$ during running, an overdischarge signal is transmitted to the control unit of the electric bus. In addition, when the battery temperature during charging and running reaches $60^{\circ} \mathrm{C}$, an overheating signal is transmitted to the control unit of the electric bus.

Figure 1 shows the structure of the batteries mounted on the electric bus. The voltage range of these battery

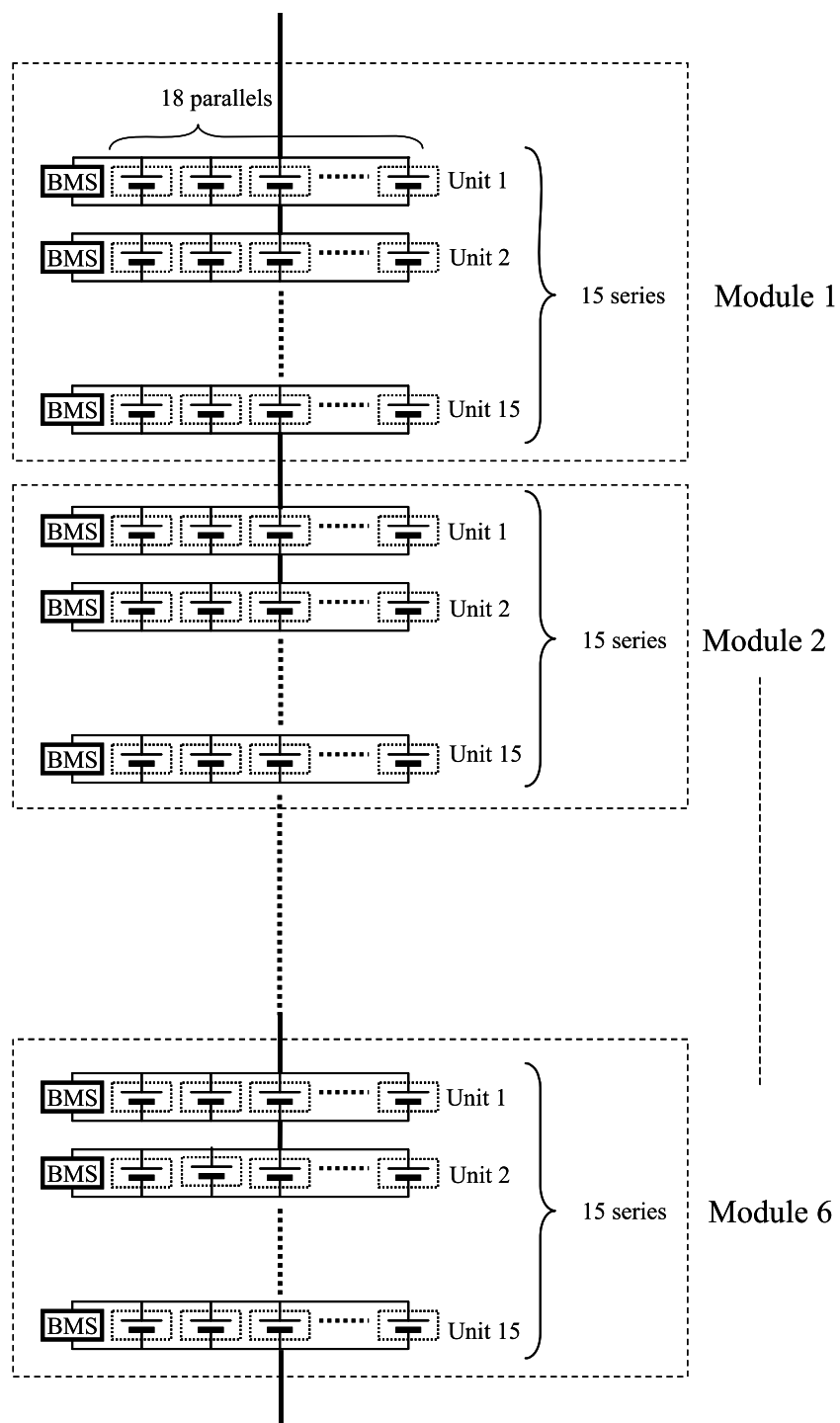

Fig. 1 Whole constitution of batteries mounted on electric bus.

modules was $270-378 \mathrm{~V}$. The rated energy capacity of the modules was $53 \mathrm{kWh}$ and the total weight of the modules was $480 \mathrm{~kg}$.

\section{2 Examination of battery characteristics using electric bus}

The test run of the electric bus was performed on a public road along a course of $1.4 \mathrm{~km}$. In the test run, the voltage and current of the batteries were recorded with a data logger.

\section{Results and Discussion}

\section{1 Characteristics of lithium manganese cathode}

The chemical composition of the manganese cathode was measured by atomic absorption spectrometry (AAS, Shimadzu, AA-6800). The molar ratios of metal components (Li:Mn) were 1.06 - 1.13:1.95. Furthermore, 5\% aluminum doping was confirmed by inductive coupled plasma (ICP) analysis.

Figure 2 shows the discharge curves of $\mathrm{Li} / \mathrm{LiAl}_{\mathrm{X}} \mathrm{Mn}_{2-\mathrm{X}} \mathrm{O}_{4}$. The rate of discharge was $1 \mathrm{C}$. The data for the case without aluminum doping are added for comparison. 


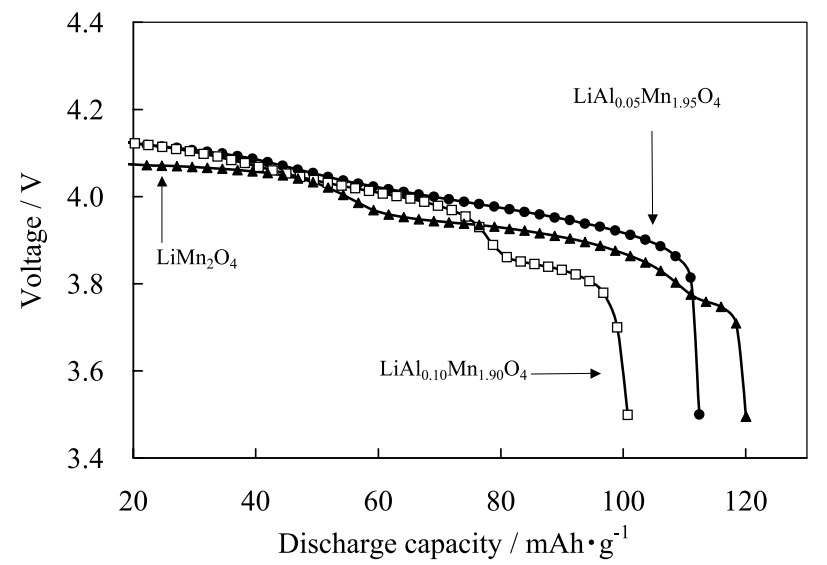

Fig. 2 Discharge curves of $\mathrm{Li} / \mathrm{LiAl}_{\mathrm{X}} \mathrm{Mn}_{2-\mathrm{X}} \mathrm{O}_{4}$ and $\mathrm{Li} / \mathrm{LiMn}_{2} \mathrm{O}_{4}$ for $\mathrm{X}=0.00,0.05$ and 0.10 . The data were measured at $25{ }^{\circ} \mathrm{C}$ with a rate of $1 \mathrm{C}$.

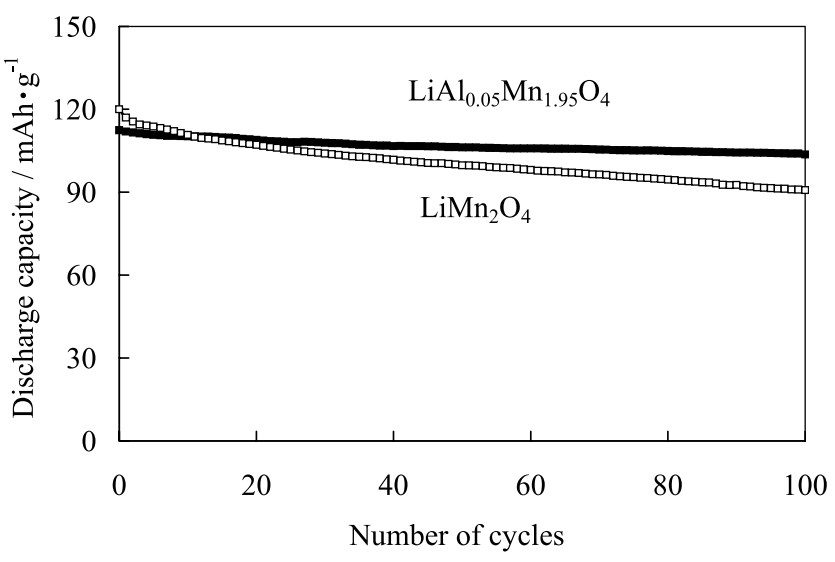

Fig. 3 Plots of discharge capacity vs numbers of cycle of $\mathrm{Li} / \mathrm{LiAl}_{0.05} \mathrm{Mn}_{1.95} \mathrm{O}_{4}$ and $\mathrm{Li} / \mathrm{LiMn}_{2} \mathrm{O}_{4}$ at $25^{\circ} \mathrm{C}$ with a rate of 1 C.

A typical voltage jump that is characteristic of the lithium manganese cathode was observed in the vicinity of $4.0 \mathrm{~V}$ in the discharge curves of $\mathrm{Li} / \mathrm{LiMn}_{2} \mathrm{O}_{4}$. However, the jump in the curve became unclear in the case of $5 \%$ aluminum doping. It was observed that the voltage had instability around $3.9 \mathrm{~V}$ in the case of $10 \%$ aluminum doping. The discharge capacity decreased to $112.4 \mathrm{~mA}$. $\mathrm{g}^{-1}$ as an effect of $5 \%$ aluminum doping, whereas $\mathrm{Li} /$ $\mathrm{LiMn}_{2} \mathrm{O}_{4}$ exhibited a discharge capacity of $120 \mathrm{mAh} \cdot \mathrm{g}^{-1}$. Furthermore, the discharge capacity decreased to 100.7 $\mathrm{mAh} \cdot \mathrm{g}^{-1}$ in the case of $10 \%$ aluminum doping.

Figure 3 shows plots of discharge capacity vs number of cycles at $25^{\circ} \mathrm{C}$. The discharge capacity after 100 cycles of $\mathrm{Li} / \mathrm{LiMn}_{2} \mathrm{O}_{4}$ decreased to $90.0 \%$ of the initial discharge capacity. It was considered to be influenced by the Jahn-Teller distortion. On the other hand, the cycle performance was improved by aluminum doping because the discharge capacity after 100 cycles was $92.2 \%$ for $\mathrm{Li} / \mathrm{LiAl}_{0.05} \mathrm{Mn}_{1.95} \mathrm{O}_{4}$. The cycle performance of the aluminum-doped manganese by internal-combustion spray pyrolysis was very stable.

Figure 4 shows plots of discharge capacity vs number of cycles at $60{ }^{\circ} \mathrm{C}$. The data were measured at $25^{\circ} \mathrm{C}$ at a

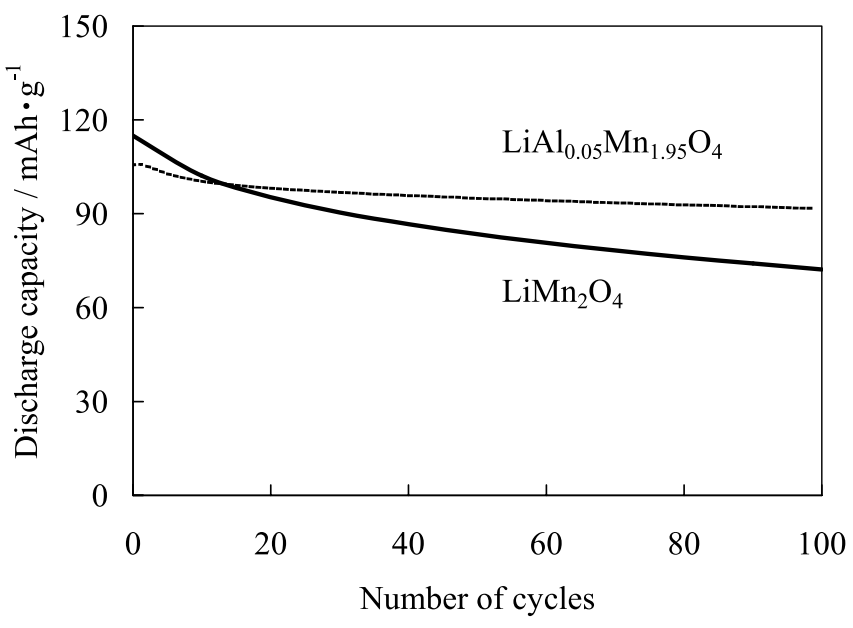

Fig. 4 Plots of discharge capacity vs number of cycles of $\mathrm{Li} / \mathrm{LiAl}_{0.05} \mathrm{Mn}_{1.95} \mathrm{O}_{4}$ and $\mathrm{Li} / \mathrm{LiMn}_{2} \mathrm{O}_{4}$ at $60{ }^{\circ} \mathrm{C}$ with a rate of 1 C.

rate of $1 \mathrm{C}$. The discharge capacity after 100 cycles for $\mathrm{Li} / \mathrm{LiMn}_{2} \mathrm{O}_{4}$ decreased to $62.8 \%$ of the initial discharge capacity. On the other hand, the discharge capacity after 100 cycles remained at $86.9 \%$ for $\mathrm{Li} / \mathrm{LiAl} l_{0.05} \mathrm{Mn}_{1.95} \mathrm{O}_{4}$. From these results, discharge capacity was found to improve at high temperatures with aluminum doping. It is thought that the dissolution of manganese at high temperatures was restrained because the average valence of manganese ions increased to more than 3.5 as a result of aluminum doping.5, 6 Therefore, cathode materials doped with $5 \%$ aluminum were adopted in the cells for the electric bus.

\section{2 Characteristics of the cells}

The average weight per laminated layered type cell of the lithium-ion battery with the cathode material of $\mathrm{LiAl}_{0.05} \mathrm{Mn}_{1.95} \mathrm{O}_{4}$ was $233 \mathrm{~g}$. Figure 5 shows the discharge curve of a cell. The discharge energy was $23.9 \mathrm{Wh}$ and the energy density was $103 \mathrm{Wh} / \mathrm{kg}$. The curve was smooth without a voltage jump. In addition, the energy density was more than $100 \mathrm{Wh} / \mathrm{kg}$, which was a responsible value.

Figure 6 shows plots of capacity rate vs numbers of cycles of the cells. The capacity of the cell not doped with aluminum decreased to $70 \%$ of the initial discharge capacity after 450 cycles and was considered to be influenced by the Jahn-Teller distortion. On the other hand, the cell doped with aluminum deteriorated to $70 \%$ of the initial discharge capacity after 850 cycles. Although the target of 1,000 cycles was not attained, the battery characteristics were improved by aluminum doping.

Figure 7 shows plots of the discharge capacity vs number of cycles of the cell doped with aluminum at $25^{\circ} \mathrm{C}$ and $45^{\circ} \mathrm{C}$. The data were measured at $1 \mathrm{C}$. The discharge capacity was maintained high and it was stable with increasing number of cycles at both temperatures. It is thought that the dissolution of manganese at a high temperature was inhibited by part of the manganese being substituted by aluminum. ${ }^{5,6)}$

Figure 8 shows the measured power densities of the cells at different states of charge (SOC). The measure- 


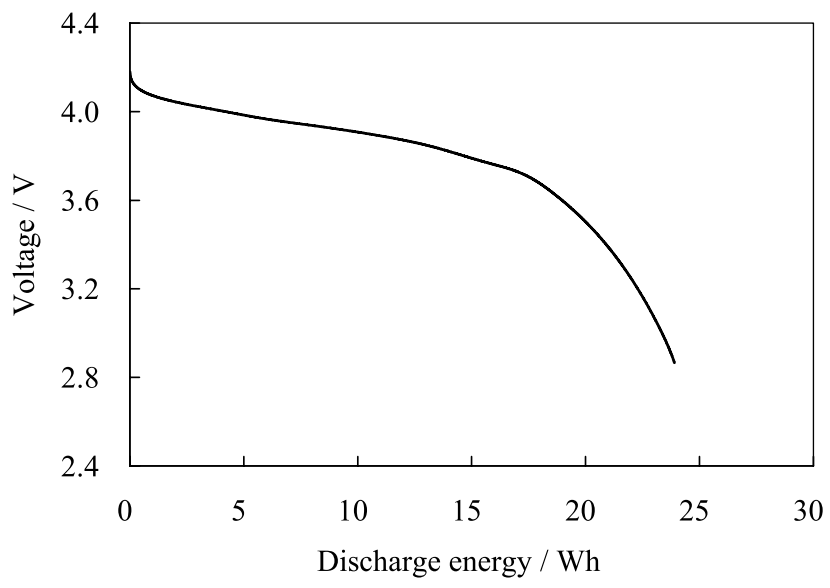

Fig. 5 Discharge curve of cell mounted on electric bus.

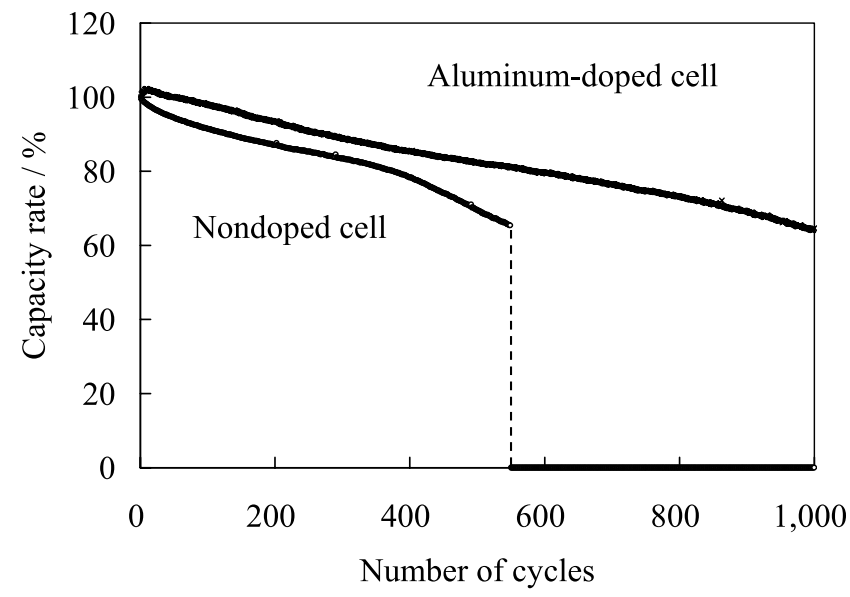

Fig. 6 Plots of capacity rate vs number of the cycles of aluminum-doped cell and the nondoped cell at $25{ }^{\circ} \mathrm{C}$ with a rate of $1 \mathrm{C}$.

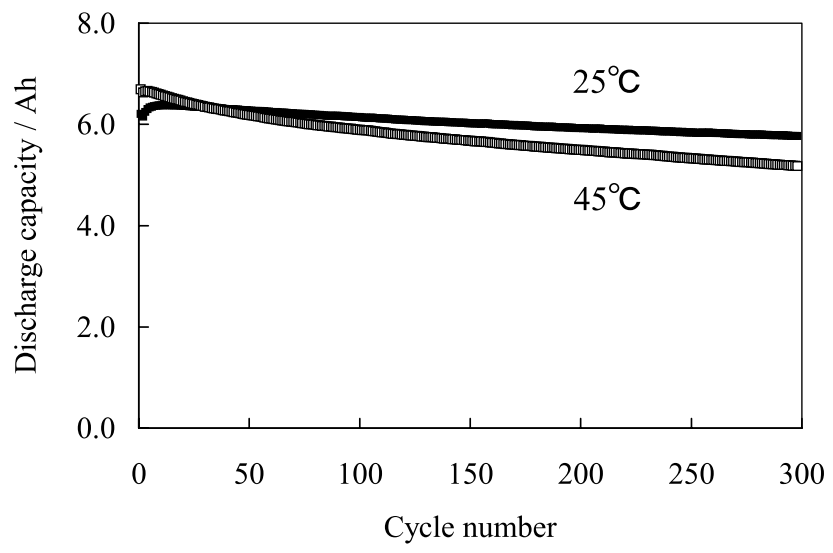

Fig. 7 Comparison of plots of discharge capacity vs number of cycles of aluminum-doped cell at $25{ }^{\circ} \mathrm{C}$ and $45{ }^{\circ} \mathrm{C}$ with a rate of $1 \mathrm{C}$.

ment of the power density was performed by impressing a pulse current on the cell. SOC of the cells were 10, 20, $35,50,65,80$ and $90 \%$. At each SOC, the rates of discharge current were $1,3,5$, and $10 \mathrm{C}$ for ten seconds. Ten seconds later, the voltage of the cell was measured.

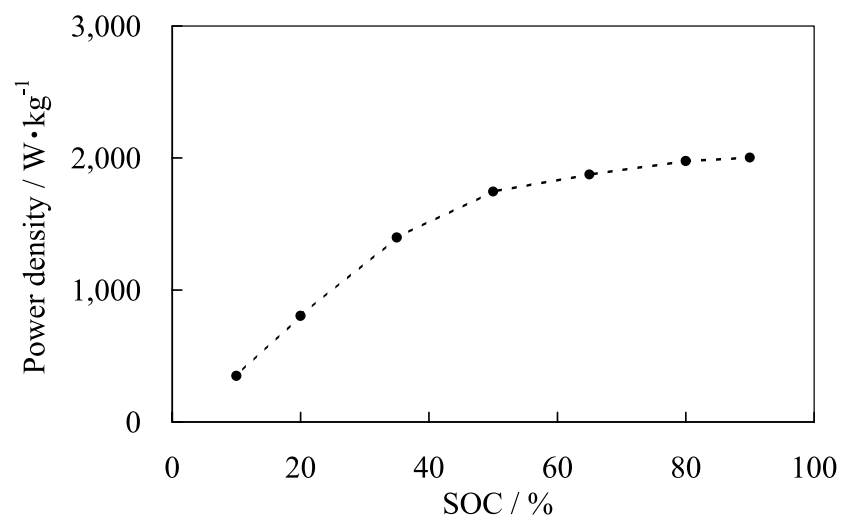

Fig. 8 Power density of cell at $25{ }^{\circ} \mathrm{C}$.

Table 2 Target characteristics and obtained values.

\begin{tabular}{l|c|c}
\hline Cathode material & $\begin{array}{c}\text { Target } \\
\text { value }\end{array}$ & $\begin{array}{c}\text { Obtained } \\
\text { value }\end{array}$ \\
\hline Discharge capacity $(\mathrm{mAh} / \mathrm{g})$ & 90 & 112 \\
\hline \multicolumn{3}{|c}{} \\
\hline Cell & $\begin{array}{c}\text { Target } \\
\text { value }\end{array}$ & $\begin{array}{c}\text { Obtained } \\
\text { value }\end{array}$ \\
\hline Energy density $(\mathrm{Wh} / \mathrm{kg})$ & 100 & 100 \\
\hline Number of cycles $(\mathrm{times})$ & 1000 & 850 \\
\hline Power density $(\mathrm{W} / \mathrm{kg})$ & 300 & 349 \\
\hline Maximum operating temperature $\left({ }^{\circ} \mathrm{C}\right)$ & 45 & 45 \\
\hline
\end{tabular}

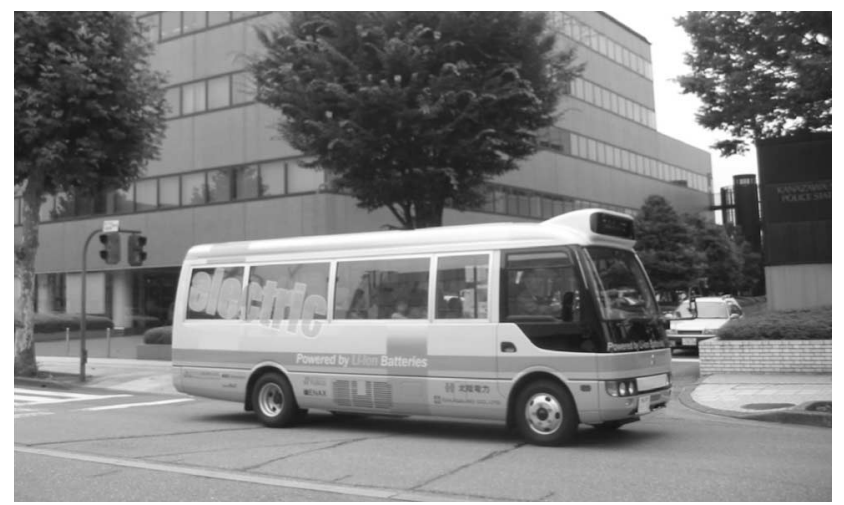

Fig. 9 Electric bus during running test.

The current at the discharge cutoff voltage was obtained from the voltage by the least-squares method. Then output density was obtained.

The range of use of the batteries was from 10 to $100 \%$ of SOC. Power density was $349 \mathrm{~W} / \mathrm{kg}$ at an SOC of $10 \%$, and $2,920 \mathrm{~W} / \mathrm{kg}$ at an SOC of $100 \%$. The cells exceeded the target value of $300 \mathrm{~W} / \mathrm{kg}$.

The target and actual values for the cells developed in this study are shown in Table 2. The performances of the battery modules were satisfactory for use in electric buses.

Figure 9 shows the electric bus, whose weight without passengers was $4,120 \mathrm{~kg}$. The original diesel-engine bus weight was 4,100 kg. The increase in weight was only 20 


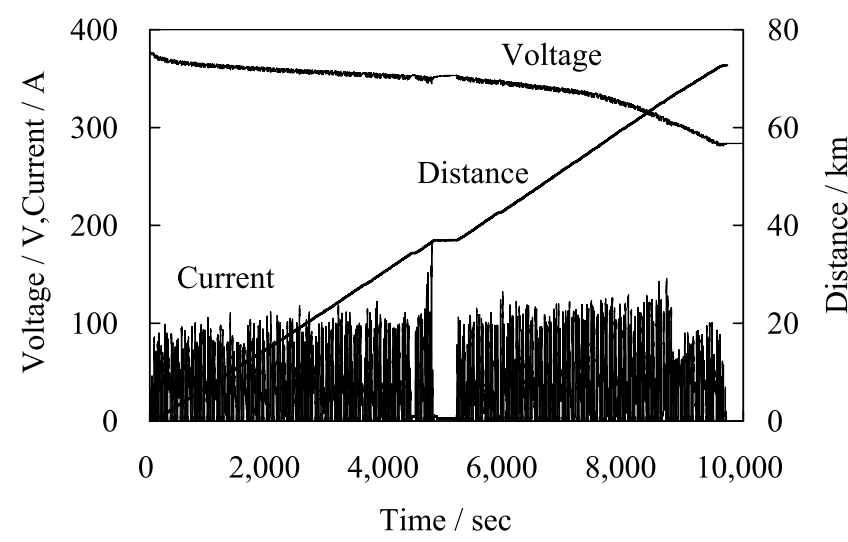

Fig. 10 Characteristics of the electric bus around a public course of $1.4 \mathrm{~km}$.

kg. The capacity of the original diesel-engine bus was 29 passengers. The electric bus has a capacity of 28 passengers because the battery modules took the space of one seat.

Figure 10 shows the characteristics of the electric bus that ran around a public course of $1.4 \mathrm{~km}$ after a full charge. The total running distance was $74 \mathrm{~km}$, which exceeded the target value of $50 \mathrm{~km}$. The electric consumption required for the run was $36 \mathrm{kWh}$. The energy consumption rate was $2.1 \mathrm{~km} / \mathrm{kWh}$, which was very near the target value of $2.0 \mathrm{~km} / \mathrm{kWh}$. In addition, the maximum power was $63.0 \mathrm{~kW}$ and the power density of the cells was $131 \mathrm{~W} / \mathrm{kg}$.

\section{Conclusions}

The maximum operating temperature of batteries to be mounted on the electric bus have been a problem that has prevented the practical use of such batteries. In particular, their deterioration at high temperature was the main problem. Also, the spinel-type lithium manganese oxide used as the cathode materials in the batteries required improvement. As a result of aluminum doping, the use of the cathode materials produced by internal-combustion spray pyrolysis resulted in improved maximum operating temperatures and cycle performance compared with those of non-doped aluminum.

The weight reduction of the batteries was another problem preventing their practical use in EVs. In particular, as the power supply of the buses increases, maintaining the capacity and extending the discharge covered $\mathrm{km}$ by improving the energy density become neces- sary.

Compared with that of conventional lead-acid batteries, the energy density of the lithium-ion batteries developed in this study was greatly improved. As a result, compared with the original diesel-engine bus, the weight of the developed electric bus without passengers was only $20 \mathrm{~kg}$ heavier. Furthermore, the capacity of 28 was only one less than that of the original diesel-engine bus.

In addition, the electric bus was able to run for $74 \mathrm{~km}$ on a full charge, which exceeded the target value of 50 $\mathrm{km}$.

These results indicate that the electric bus is applicable for short-distance use, for example, as a community bus or a pickup bus.

The lithium-ion batteries developed in this study generally satisfied the characteristics required for use in an electric bus such as the energy density, power density, maximum operating temperatures and number of cycles.

\section{Acknowledgement}

This work is partly supported by the Ministry of Economy, Trade and Industry as a Consortium R\&D project for regional revitalization.

\section{References}

1) K. Yamasaki, M. Fukuda, T. Nojima, and S. Taniguchi, Proc. of the 2000 Japan Industry Applications Society Conference, 1, 349 (2000) [in Japanese].

2) H. Ozawa, T. Ogihara, and K. Ozawa, Electrochemistry, 3, 76 (2008).

3) Y. Gao, J. N. Reimers, and J. R. Dahn, Phys. Rev. B., 54, 3878 (1996).

4) A. Yamada and M. Tanaka, Mater. Res. Bull., 30, 715 (1995).

5) A. de Kock, E. Ferg, and R. J. Gummow, J. Power Sources, 70, 247 (1998).

6) R. J. Gummow, A. de Kock, and M. M. Thackeray, Solid State Ionics, 69, 59 (1994).

7) I. Mukoyama, K. Myojin, T. Ogihara, M. Uede, H. Ozawa, and K. Ozawa, Key Eng. Mater., 320, 251 (2006).

8) K. Myojin, T. Ogihara, N. Ogata, N. Aoyagi, H. Aikiyo, T. Ookawa, S. Omura, M. Yanagimoto, M. Uede, and T. Oohara, Adv. Power Technol., 15, 397 (2004).

9) S. Motohira, T. Ogihara, I. Mukoyama, T. Nakamura, H. Ozawa, K. Fujii, M. Uede, N. Ohnuma, T. Futakuchi, T. Watanabe, and H. Morino, WEVA J., 1, 165 (2007).

10) S. Motohira, H. Morino, Y. Matsumoto, and T. Ogihara, Proc. of the $\mathbf{2 0 0 7}$ Japan Industry Applications Society Conference, 2, 181 (2007) [in Japanese]. 